\title{
Colloquiality in the style of contemporary Czech journalistic writing
}

\author{
P. Mareš \\ Charles University, \\ 2, Jan Palach square, Prague, 11638, Czech Republic
}

For citation: Mareš, P. (2019). Colloquiality in the style of contemporary Czech journalistic writing. Media Linguistics, 6(1), 48-59. https://doi.org/10.21638/spbu22.2019.104

Contemporary Czech journalistic writing increasingly makes use of language means which are primarily associated with spoken, spontaneous and private communication. This trend, which is called conversalization, colloquialization, informalization, etc., is briefly characterized in the first part of the article. The authors of journalistic texts make use of colloquial (informal) language means (colloquialisms), mainly in order to lessen the distance between the actors of communication as well as to better approximate the supposed speech habits of the recipients. At the same time, such texts raise the sense of immediacy, ease, naturalness and emotional engagement. They also attract attention to their own linguistic construction. The recurrent use of colloquialisms naturally leads to a loss of their impact. Their difference to synonymous terms hitherto regarded as standard and unmarked thus diminishes. The promotion of colloquialisms may reach the point whereby these terms become neutralized and push previously neutral terms to the point of becoming peripheral (bookish or antiquated). The main part of the article describes the occurrence of two types of colloquial lexical items in contemporary Czech journalistic texts. The areas of focus are as follows: (a) Univerbized words (such as kulturák 'cultural centre'; lahváč 'bottle of beer') and abbreviated words (such as kilák 'kilometre'), which are shorter than the standard expressions and often more of expressive and emphatic; (b) loanwords of German origin (for example mord 'murder').

Keywords: colloquiality, journalistic texts, univerbization, abbreviation, loanwords from German in Czech.

Problem Description. One of the distinguishing features of contemporary public verbal communication - especially communication in the media, media discourse [see Fairclough 1995; Hoffmannová et al. 2016: 255, 295; Schneiderová 2013; Schneiderová 2015: 89-149] - is without doubt the pervasion of language means and formulations that are primarily used in non-public communication (private or professional albeit unofficial). This trend has been the object of attention of many researchers and various propositions as to its overall denomination have been submitted: conversalization, colloquialization, informality, i.e. informalization, conceptual orality, etc. In this article I will be focusing on the elementary characterization of the phenomenon in question in relation to various terminological concepts (concentrating essentially on the Czech linguistic context) and primarily I will be describing several kinds of language means which are associated with this, and which are being foregrounded in contemporary Czech journalistic writing. I will also observe their impact on the style of journalistic texts.

(c) Санкт-Петербургский государственный университет, 2019 
History of the issue. The reflections of Norman Fairclough have fundamentally influenced the discussions surrounding the developments in media discourse. Amongst other things, he pointed out a tendency toward the democratization of public discourse, which rests on "the removal of inequalities and asymmetries in the discursive and linguistic rights, obligations and prestige of groups of people" [Fairclough 1992: 201]. According to Fairclough, the push to diminish inequalities has led to a growth in informality, which has manifested itself most especially in the promotion of conversational discourse from the private to public sphere; hence conversation "is colonizing the media" [Fairclough 1992: 204]. The concept of conversalization has also evolved in relation to the Czech context. Its basic feature is considered to be a linguistic freeing-up. This is meant to weaken the authoritarian attitude associated with the author of the text and replace it with affability, graciousness and a sense of accommodation towards the recipients whilst at the same time there is an air of servility and ingratiation [Čmejrková 2011: 283].

Colloquialization is sometimes regarded as a counterpart of conversalization, sometimes as a component of it. In colloquialization, the linguistic trend "from formality to informality" comes to the foreground. This is manifested in the public use of language means habitual in the private sphere, particularly in oral communication; non-standard and expressive words as well as a "flowing", less elaborate syntactic structure of utterances are often found [Hoffmannová 2008: 64, 66; Hoffmannová 2011:323]. Soňa Schneiderová likewise characterizes colloquialization as a growth in informality and links it to the attempt to adapt the language used in media texts to the everyday speech of the recipients. At the same time the expressivity of the chosen language means is highlighted, founded on an aspiration "to influence the emotional level of the recipient's perception" [Schneiderová 2015: 94].

To date I have mostly preferred the term informality [Mareš 2012]. The aim was to bring attention to the breaking or ignoring of established norms of public communication, to the significant freeing-up and effortlessness of language expression and to the manifestation of spontaneity and emotional engagement, which are, however, often simulated and not authentic. A simulated weakening of the distance between author and recipient and the building of a mutually close relationship are associated with this.

It is also worth reminding ourselves of the influential concept of communicative immediacy and distance suggested by German linguists Peter Koch and Wulf Oesterreicher [Koch \& Oesterreicher 2008; Koch \& Oesterreicher 2012]. The starting-point for them was the distinction between medial orality and literacy as opposed to conceptual orality and literacy. The medial orality and literacy here signify the realization of a text through the articulation of sounds on the one hand and through writing on the other. Conceptual orality and literacy are based on a set of linguistic and communicative features (with dichotomies such as private - public, dialogical - monological, spontaneous - reflective). A pole of prototypical orality, which is characterized by communicative immediacy, and a pole of prototypical literacy, which is characterized by distance, is thus formed. "On a scale between these two poles, all kinds of text types can be located according to their degree of linguistic 'immediacy' or linguistic 'distance', respectively" [Elspass 2012: 157]. Processes in the sphere of public communication (which traditionally has been characterized by conceptual literacy) can be so described as a shift in the direction of conceptual orality, i. e. communicative immediacy. 
Two conclusions may be deduced from this partial overview: (a) Although the terms used frequently have their origins in the sphere of orality, the phenomena under discussion are apparent in both spoken as well as written public communication. (b) The aforementioned terms represent takes on the same reality, whereas different aspects are highlighted, i. e. their hierarchy is perceived differently.

Although the term colloquiality will primarily be used here, it will be simultaneously a discourse on informality. I speak in terms of colloquiality because I am focusing on lexical expressions which are widespread and unmarked in spoken private (or professional) communication and which increasingly pervade public communication, specifically written media texts.

Methodology of the study. Evidence of the strong pervasion of colloquialisms is founded on the fact of their extensive occurrence in the so-called quality press. The following analysis is based primarily on extracts from the nationwide Czech dailies Mladá fronta Dnes (MFD), Lidové noviny (LN) and Právo (P). Some quotations were obtained from the representative synchronous corpus of Czech language SYN2015 [Křen et al. 2015], which comprises of 100 million tokens (from texts published between 2010 and 2014). In addition to this, I make use of my own excerpts from Czech journalistic texts which I have collected over the course of several years. The monitoring of complete texts allows for not only the recording of occurrences of individual expressions but also for the description and analysis of the treatment of these expressions in a broader context. It enables us to register the relationships between the colloquialisms used and the standard lexical items as well as the use of synonymity, etc. On the basis of this, it is possible to draw certain conclusions regarding the style and the development of style of Czech journalistic texts.

Material Analysis. Colloquiality in Czech journalistic texts is particularly apparent in terms of univerbized expressions (and to a lesser extent abbreviated expressions too). Univerbization (in its basic form) consists of the "creation of one-word expressions from multi-word expressions by adding a suffix to the derivative base of one of its components" [Kolářová 2011: 281; emphasized by I. K.] Opposing each other are a multi-word expression and the semantically (although by no means always stylistically) equivalent result of univerbization, i.e. a univerbizate. Univerbizates are often coined in everyday, and particularly oral, communication. They spread and become preferred to their multiword counterparts. The common principle of economy is at play here: priority is given to expressions which allow for the transfer of information with the use of less energy and in a shorter time (or on a smaller surface). What is more, univerbizates frequently exhibit expressive markedness with which it is possible to manifest an emotional attitude, and furthermore, a feature of ease as well as a distinctiveness and impact. A similar position is occupied by abbreviated expressions, which are formed by the removal of a part of the original expression; sometimes a word-building suffix is added.

I have demonstrated in an earlier article [Mareš 2014: 103-104] that two basic sets of word-building suffixes are used for univerbized and abbreviated expressions in Czech. The second of these sets is more marked and is more inclined to an expressive use:

-ák: animák < animovaný film 'animated film'; časák < časopis 'magazine';

-ka: záchranka < záchranná služba 'rescue service'; plovka < plovárna 'swimming pool'; 
-ko: stavebko < stavebni spořeni 'building savings'; solárko < solárium 'solarium';

-ky: primátorky < primátorské závody 'Mayor's Shield Regatta'; narozky < narozeniny 'birthday';

-áč: animáč < animovaný film 'animated film'; hambáč < hamburger 'hamburger';

-ča: dovča < dovolená 'holiday';

-čo: intimčo < intimní prádlo 'underwear'; mimčo < mimino 'baby';

-áče: punčocháče < punčochové kalhoty 'tights'.

The above examples indicate that the univerbized (abbreviated) expressions are characterized by heterogeneity in several aspects: Even though an overwhelming majority of these expressions have evidently been formed and have spread within the scope of everyday spoken communication, it is possible to suppose that some have been expressly created according to an established model for the purpose of public communication. This is borne out both by how significant the set of words under discussion is (relating as they do to institutions in economic and social fields) and by their frequent occurrence in texts concerned with marketing and advertising. In addition to stavebko there are the following examples: důchodko < di̊chodové připojištění 'pension scheme', havarijko < havarijní pojištěni 'accident insurance' or životko < životní pojištění 'life insurance'. The names of financial institutions are treated in a similar way: komerčka $<$ Komerční banka 'Commercial Bank', raifka < Raiffeisenbank, spořka < Česká spořitelna 'Czech Savings Bank'.

A more complicated and dynamic issue relates to the stylistic colouring of univerbized and abbreviated expressions and to their relationship to the stylistic colouring of the original lexical items. Individual expressions occupy different positions. In addition, shifts in their stylistic validity often occur. Determining the stylistic classification, and in particular the positions of individual expressions within its framework, is thus a considerably arduous task. Whilst older dictionaries operated on the traditional divisions of standard neutral Czech, standard spoken ("colloquial") Czech, vernacular ("common") Czech and slang, Ivana Kolářová, in her comprehensive treatment of univerbization, suggested categorization into five groups based on various criteria [Kolářová 2011, 304-305]. She divides univerbizates into standard marked (terminological) items (e.g. převodovka 'gearbox') and standard neutral items (e. g. minerálka 'mineral water'), followed by substandard terms with a low degree of expressivity (e.g. panelák 'prefabricated block of flats'), substandard ones with a middle degree of expressivity (e.g. décák 'children's home') and those with a high degree of expressivity (e.g. tlakáć 'pressure cooker').

Whilst we may regard this differentiation as adequate and appropriate, there remain the complications in relation to the classification of individual words. In addition, this classification does not have to be identical for different users of language. For example, the expression panelák has evidently lost its aspect of expressivity for many speakers of Czech and is now seen as a standard word by them.

The pervasion of the given expressions into public texts plays an important role here. As a rule colloquialisms in these texts have retained, at least for a certain period of time, a feature of substandard, and in some cases an aspect of expressivity, and therefore their markedness. Colloquialisms often initially come into public communication as part of quoted utterances (they represent "foreign speech") or they are provided with quotation 
marks that function to signal distance. However, many of these expressions gradually become an integral, unmarked component of public texts. As long as they spread, their markedness diminishes and they cease to draw attention to themselves. This has various sorts of consequences including shifts in the stylistic colouring of newly-formed as well as established expressions.

Some univerbized or abbreviated expressions (amongst others: činžák 'apartment building', panelák 'prefabricated block of flats', spacák 'sleeping bag', punčocháče 'tights', fotit 'take snaps') have become part of public communication to such an extent that they clearly now dominate the long-established terms. As a result, they tend to become the standard terms and the previously neutral terms are being sidelined and becoming marked (bookish or antiquated). For example, in the SYN2015 corpus we can find 826 occurrences of the expression panelák against 397 occurrences of the expression panelový dirm, 400 occurrences of the term spacák against 160 occurrences of spací pytel, and 1833 occurrences of the verb fotit against 1033 occurrences of fotografovat.

Even in cases where such developments have not occurred (at least for the moment), there is present a weakening of the stylistic difference in regard to the multi-word (unabbreviated) expressions. The effect of colloquiality then is overshadowed by the attempt to attain a diversity of formulations (expressive dissimilation). The result is that several expressions that are regarded as synonymous and without essential stylistic difference alternate in texts. As a result, the colloquialisms in media texts sometimes maintain and make use of the aspect of spoken ease, immediacy or expressivity but sometimes they come into play more as an attempt to avoid monotonous formulations. Furthermore, the principle of economy is important - the option of choosing a shorter expression is generally welcome in journalistic texts.

In relation to the dual nature of the observed colloquialisms, a number of questions come to the foreground: In which genres and columns of newspapers (and magazines) are univerbized and abbreviated expressions frequent? In which part of the texts are these terms preferred? To what extent do they have qualities associated with private communication? What relationships occur in texts between these expressions and their multi-word (unabbreviated) counterparts? Naturally, only partial observations can be presented here.

(a) Univerbized and abbreviated expressions are very often used in sports journalism. Many of them originate in sports slang and are linked to the emotional attitudes of sports people and others involved in sport. On the pages of newspapers and magazines they usually start out as part of quoted utterances, they are then used in connection to the quotations and gradually they become part of the author of the text's "own" speech.

For example, the expression světák (< světový rekord 'world record', světový šampionát 'world championship') finds its way into the texts in most cases as a part of quoted speech:

[1] „[...] on chtěl světák. Bylo vidět, jak si věr r' " [P, 31.1.2011]. ('[...] he wanted the world record. It was clear how much he believed in himself.') (My emphasis in all quotations.)

[2] „Jen jsem na světáku v Kanadě potřebovala zajet dobrý výsledek“ [P, 29.1.2014]. ('I just needed to get a good result at the world championship in Canada.')

The journalists often use such words in reference to a concrete utterance or usage by the sports people:

[3] [...] o to větší vzrušení však dobýváni „světáku“ nabízí [MFD, 27.1.2012]. (“[...] but the gaining of world record offers all the greater excitement.') 
Nevertheless, we can come across cases where the aspect of distance is lost and the need for avoiding repetition of the same word becomes prominent:

[4] Jarmila Kratochvílová dodnes drží světový rekord v běhu na 800 metrů. [...] Její největši sokyně (východo)Němka Marita Kochová dodnes drží světák na 400 metrů [MFD, 29.1.2011]. ('Jarmila Kratochvílová still holds the world record at 800 metres. [...] Her greatest rival (Eastern) German Marita Koch still holds the world record at 400 metres.')

The way in which colloquialisms from sport are dealt with is also seen, for example, in an article where the abbreviated term kilák ('one-kilometre race' in this case) is used. A canoeist in the context of an interview stated:

[5] A ani jsem nechtěl jet další kilák, přece jen dost bolí [P, 25.8.2017]. ('And I didn't really want to do another 1-k race, it still really hurts.')

His utterance is then transformed into a quite striking headline:

[6] Kilák bolí. Nechtěl jsem jet další navíc. ('The 1-k hurts. I didn’t want to do another one.')

(b) The regional news is another field in which there are abundant occurrences of the sort of colloquialisms under discussion. Authors of texts on current affairs in individual towns or regions often use colloquial (predominantly univerbized) forms of oikonyms and anoikonyms [see Prošek 2005]. In this way the immediacy for the local readers, who are the intended first-choice recipients of the message, is increased. As a rule a univerbizate appears as a prominent element in the headline, whereas the standard synonymic expression is used at the start of the article (or frequently in the subhead), and then there is an alternation of both expressions in the main body of the text:

[7] Na Václaváku je nový bezbariérový přechod [headline - H]. V horní části Václavského náměstí je od posledního dubnového dne v provozu nový bezbariérový prechod [MFD, 3.5.2010]. ('On Wenceslas Square there is a new barrier-free pedestrian crossing. A new barrier-free pedestrian crossing has been in operation in the upper part of Wenceslas Square since the last day of April.')

[8] První nájemníci přrišli na „Jižák“ před 40 lety [H]. [...] Dnes si však obyvatelé život mezi panelovými domy Jižního Města pochvalují. [...] O vybudování tzv. „Jižáku“ (lidový výraz pro Jižní Město) se uvažovalo od 60. let [MFD, 26.9.2016]. ("The first tenants arrived in "Jižák" 40 years ago. [...] Today, however, the inhabitants have nothing but praise for life amongst the prefabricated blocks of South Town. [...] The construction of so-called "Jižák" [a colloquial term for South Town] was considered since the 60s.')

Similarly, univerbized appellatives appear in texts about local business establishments as well as cultural or sporting facilities:

[9] Do nového života vykročili v obchod'áku [H]. Netradiční pohled včera zažili návštěvníci obchodního centra Šestka [MFD, 2.10.2010]. ('They took their first steps to a new life in a shopping centre. Visitors to the Šestka shopping centre witnessed an unusual sight yesterday.)

[10] Vítr [...] poškodil kostel, kulturák i hřbitov [H]. [...] Po něm zưstala poškozená $i$ střecha kulturního domu [MFD, 24.8.2012]. ('The wind [...] damaged the church, cultural centre and cemetery. [...] It resulted in damage to the roof of the cultural centre, too.') 
(c) Colloquialisms also pervade texts focusing on more common themes (social, political and economic). Mostly this relates to the naming of things and phenomena which have an impact on everyday life (names of state institutions, public transport, bills, cards, licences, goods on the market, etc.). Official matters are thus brought near to the sphere of the everyday.

The "career" of the univerbizate lahváč (< lahvové pivo 'bottled beer') is telling. Its infiltration into journalistic texts was facilitated by situations where specific human behaviours are discussed or when it is a question of dealing with the beverage.

[11] [...] na autobusové zastávce [...] kouři a popijí právě zakoupené lahváče několik mužů $z$ vesnice [P, 25.10.2014]. ('[...] several men from the village are smoking and drinking from bought bottles of beer [...] at the bus stop.')

[12] [...] tolik stupřů by měl mít i obyčejný lahváč [MFD, 9.2.2011]. ('[...] and even ordinary bottles of beer should have such a degree of temperature.)

Gradually, however, the term lahváč finds its way into general economic contexts (related to production and consumption):

[13] Češi loni vypili méně piva, šetríli na lahváčích [H] [MFD, 9.4.2010]. ('Last year Czechs drank less beer, they saved on bottled beer.')

[14] „Lahváće“ ustupují, roste obliba piva v plechovce [H] [MFD, 8.4.2016]. ('Bottled beer is on the retreat and the popularity of canned beer is increasing.)

Exclusive occurrence of this univerbizate in an article written by an "economist" and "external advisor to the finance minister" is a telling illustration of its journey to a neutral state. The article is concerned with innovations in economic development:

[15] Nedaleko hospody je tady obchod se slevou na lahváče. Ten prachobyčejnýlahváč je pro hospody daleko větším narušitelem než EET. [...] na lahváče a plechovky připadalo 44\%. [...] lahváče a plechovky z celkového množství vypitého piva tvoří $60 \%$. [...] lahváč není zas tak zásadní [...] [MFD, 13.12.2016]. ('Not far from the pub here is a shop with a sale on bottled beer. This ordinary bottled beer is by far a bigger threat to pubs than the electronic receipt system. [...] bottled beer and cans have fallen by $44 \%$. [...] bottled beer and cans make up $60 \%$ of the entire amount of beer consumed. [...] the bottle of beer isn't so indispensable.')

There has been a considerable spread in the use of, for example, expressions relating to transport. Ǩidičák (< řidičský průkaz 'driving licence') appeared a number of years ago. Nowadays we come across such words as techničák (< technický průkaz 'certificate of roadworthiness'), osobák (< osobni vũz 'private vehicle'), kruháč (< kruhový objezd 'roundabout'), etc. These univerbizates often alternate with respective multiword expressions; the need for differentiation of co-referring terms is thus foregrounded:

[16] Na „kruháčích“ hrozí zácpy a nehody [H]. Novela silničního zákona mění pravidla pro přednost $v$ jízdě na kruhových objezdech. [...] vozidlo jedoucí po „kruhácii“ má prednost jízdy [MFD, 24.3.2016]. ('Roundabouts are threatened with traffic jams and accidents. A new rule in the Highway Code changes the priority on roundabouts. [...] the vehicle going around the roundabout has priority.) 
Recently we have also witnessed a distinct pervasion of univerbizates into texts which are concerned with financial or legal questions:

[17] Výběr „spotřebky“ loni trhl rekord [H]. Celní správa loni vybrala na spotřebních daních 148 miliard korun [MFD, 7.1.2016]. ('The collection of excise duty reached a record last year. Customs and Excise collected 148 billion crowns in excise duty last year.')

[18] Nový rodičák. Kratší, bohatší [H]. Rodiče budou moci čerpat vyšší rodičovský príspěvek a vrátit se dříve do práce [MFD, 27.2.2016]. ('New family allowance. Shorter, richer. Parents will be able to access a higher family allowance and return to work earlier.')

(d) As a rule abbreviated terms display a greater degree of expressivity in relation to their base terms; therefore they appear rarer in journalistic texts. One example (kilák) has already been given above; below we may add some further examples:

[19] Dovča s princem [H]. Zelená dovolená po stopách prince Charlese [Květy, 2011, No 6]. ('Hols with a prince. A green holiday in the footsteps of Prince Charles.')

[20] [...] když se nám chce v hospodě (v divadle, na fest'áku, ve vlaku) čuorat [MFD, 20.7.2015; standard form: festival]. ('[...] when we feel like peeing in the pub [theatre, festival or train].')

[21] Složení jídla v sámožce neovlivníte, tady ano [Reflex, 2016, No 25; standard form: samoobsluha]. ('You can't influence the composition of food in a supermarket but here you can.')

A small but still growing group of colloquialisms that are appearing in Czech journalistic texts are evidently loanwords from German (or through German from other languages - often originally from Latin). These lexical items were essentially diffused into the sphere of private communication from public and official communication mainly in the second half of the 19th century. A fair amount of these expressions disappeared or became marginalized. Those that held on are often associated with an expressive markedness, which is mostly negative (ksicht 'face', hajzl 'toilet'/'crook', šmejd 'a piece of junk'/'crook').

Nevertheless, journalistic texts show that some of these loanwords have found their way into contemporary public communication. The stimuli for this are evidently similar to those in the case of univerbized and abbreviated expressions. The markedness of loanwords is exploited (that is why they are often found in headlines) whilst at the same time this markedness is weakened by the fact that they alternate in the texts with their basic Czech equivalents.

The word partaj ('political party') may be seen as something of a pioneer. Originally it mainly appeared in private communication and as a rule was characterized by an expressive markedness. For several years now (at least since 2010) this expression has become more or less an unmarked synonym of the basic term politická strana. These alternatives are often applied equally to the same political body:

[22] [...] největší pravicová strana [...] ODS pak prohrála o více než pět procent a Klausovy dny $v$ čele partaje byly sečteny [MFD, 17.3.2010]. ('[...] the biggest right-wing party [...] ODS has lost by more than five percent and Klaus's days as its head were numbered.') 
[23] Lidé prostě v řešení migrační krize pořád více věři standardním partajím než antimigračně naladěným stranám [MFD, 11.4.2016]. ('When it comes to the immigration crisis, people quite simply have more faith in the traditional parties that the anti-immigration ones.')

The expression špitál ('hospital') has spread in a similar way; it has both become a popular striking feature of headlines and begun to be accepted as the full-value equivalent of the standard expression. In articles about problems in healthcare, this allows for the avoidance of unending repetitions of the word nemocnice:

[24] Jaký špitál? Poradí interaktivní mapa [H]. Resort zdravotnictví na rozdíl od krajů neví, co se v jeho nemocnicích děje [MFD, 18.9.2015]. ('Which hospital? An interactive map advises. The health department, unlike the regions, doesn't know what is happening in its hospitals.')

[25] Policie uzavřela př́pad možné šikany mezi zdravotními sestrami v děčínské nemocnici. Ve špitále se odehrály dva incidenty [...]. Nemocnice spadá pod firmu Krajská zdravotní, [...] která spravuje pět největších špitálů v regionu [LN, 2.9.2017]. ('Police have closed the case of possible bullying amongst nurses in a Děčín hospital. Two incidents had taken place in the hospital [...]. The hospital comes under the Regional Healthcare group, [...] which runs five of the biggest hospitals in the region.')

The word cifršpion ('beancounter', literally 'number spy') has been used extensively in connection with employees of the Finance Analysis Division (later Finance Analysis Office) of the Czech Ministry of Finance. It is noteworthy that neutral terms such as účetni ('accountant'), kontrolor účtu ('accounts manager') or auditor ('auditor') have been practically expunged from the texts, and that cifršpion is now seen as an "adequate" way of naming these professions:

[26] Šéf cifršpionů havaroval [H]. Ředitel Finančního analytického útvaru ministerstva financí Milan Cícer mél autonehodu [LN, 30.11.2013]. ('Beancounter boss has had an accident. The director of the Finance Analysis Division of the Ministry of Finance, Milan Cícer, has had a car accident.')

[27] Cifršpioni zmrazili miliardy pro Tykače [H]. [...] Cifršpioni z FAÚ oznámili transakci policii [MFD, 8.12.2015]. ('Beancounters froze billions for Tykač. [...] Beancounters from FAD have notified police of the transaction.')

The tendency for this type of loanwords to be used in journalistic texts, and their assumed acceptance in public communication, is confirmed by a further series of quotations:

[28] Kratochvíl spatřuje príčinu [...] v [...] mizerné bytové politice státu s nedostatkem sociálních a startovacích kvartýrů [LN, 19.12.2015]. ('Kratochvíl sees the cause $[\ldots]$ in $[\ldots]$ the dire housing policy of a state lacking council flats or ones for first-time buyers.')

[29] Za tajemný mord hrozí muži doživotí [H]. [...] Za trestné činy krádež a vražda hrozí muži patnáct až dvacet let za mř́žemi [MFD, 9.9.2016]. ('Man threatened with life for a dark murder. [...] Man is threatened with fifteen to twenty years inside for theft and murder.')

[30] Nový př́stroj šmíruje buňku v těle jako rentgen [H]. [...] Technologie [...] umí přesně sledovat život buňky [MFD, 9.2.2016]. ('A new device snaps cells in the 
body like an x-ray. [...] Technology [...] precisely knows how to follow the life of a cell.')

Results of the study and conclusion. The quoted utterances (which are chosen from a wide sample) demonstrate that the presence of colloquial expressions have become a significant feature of contemporary Czech journalism (including so-called quality journalism).

It can be assumed that more words of this type will permeate into Czech journalistic texts and that the attempts to bring the language means used nearer to the habits and preferences of the readers (and in this way enhance the attraction of newspapers and magazines) will continue. At the same time it is true that the increasingly frequent use of a certain word will clearly diminish its markedness (at least from the authors' perspective) and that it will begin to be used more or less as an equivalent of the basic standard lexical item. Thus, the mechanism, which in terms of the Prague School is seen as a tension between foregrounding and automatization, continues to assert itself. 1

\section{References}

Čmejrková, S. (2011). Mluvená čeština v různých podobách mediálního dialogu [Spoken Czech in Various Forms of Media Dialogue]. In S.Čmejrková \& J.Hoffmannová (Eds.), Mluvená čeština: hledání funkčního rozpětí [Spoken Czech in Search of Functional Range] (pp. 253-309). Praha: Academia.

Elspass, S. (2012). The Use of Private Letters and Diaries in Sociolinguistic Investigation. In J. M. HernándezCampoy \& J. C. Conde-Silvestre (Eds.), The Handbook of Historical Sociolinguistics (pp. 156-169). Malden, MA - Oxford: Wiley-Blackwell.

Fairclough, N. (1992). Discourse and Social Change. Cambridge: Polity Press.

Fairclough, N. (1995). Media Discourse. London: Edward Arnold.

Hoffmannová, J. (2008). Současné možnosti a trendy popisu mluvené češtiny (se zaměřením na kolokvializaci a konverzacionalizaci) [Contemporary Possibilities and Trends in Description of Spoken Czech (with Orientation on Colloquialization and Conversalization)]. Slavia, 77(1-3), 63-75.

Hoffmannová, J. (2011). Kolokvializace a konverzacionalizace: novinová a časopisecká interview mezi psaností a mluveností [Colloquialization and Conversalization: Interviews in Newspapers and Magazines between Literacy and Orality]. In S. Čmejrková \& J. Hoffmannová (Eds.), Mluvená čeština: hledání funkčního rozpètí [Spoken Czech in Search of Functional Range] (pp. 323-347). Praha: Academia.

Hoffmannová, J. et al. (2016). Stylistika mluvené a psané češtiny [The Stylistics of Spoken and Written Czech]. Praha: Academia.

Koch, P., Oesterreicher, W. (2008). Mündlichkeit und Schriftlichkeit von Texten [Orality and Literacy of Texts]. In N. Janich (Ed.), Textlinguistik: 15 Einführungen [Text Linguistics: 15 Introductions] (pp. 199215). Tübingen: Gunter Narr.

Koch, P., Oesterreicher, W. (2012). Language of Immediacy - Language of Distance: Orality and Literacy from the Perspective of Language Theory and Linguistic History. In C. Lange, B. Weber \& G. Wolf (Eds.), Communicative Spaces: Variation, Contact and Change - Papers in Honour of Ursula Schaefer (pp. 441-474). Frankfurt a. M.: Peter Lang.

Koláŕová, I. (2011). Univerbizace [Univerbization]. In F. Štícha (Ed.), Kapitoly z české gramatiky [Chapters from Czech Grammar] (pp. 273-410). Praha: Academia.

Křen, M. et al. (2015). SYN2015: reprezentativní korpus psané češtiny [SYN2015: Representative Corpus of Written Czech]. Praha: Ústav českého národního korpusu FF UK [Institute of Czech National Corpus CU FA]. Retrieved from http://www.korpus.cz.

${ }^{1}$ This article is an amended and abbreviated version of the text originally printed in Czech - Slavia 87 (1-3), 2018, 227-238. The English version was supported by the following grant: GA ČR 18-08651S Mixing genres, styles and discourses in contemporary Czech public communication. 
Mareš, P. (2012). Neformální slovní zásoba v současné sportovní publicistice: „Fotbalové deníky“ Jaromíra Bosáka [Informal Vocabulary in Contemporary Sports Journalism. "Football Diaries" by Jaromír Bosák]. In H. Burkhard \& R. Hammel (Eds.), Sprache im Kulturkontext. Festschrift für Alicja Nagórko [Language in Cultural Context. Papers in Honour of Alicja Nagórko] (pp. 37-44). Frankfurt a. M.: Peter Lang.

Mareš, P. (2014). Světák, dovča a spol.: K neformálním pojmenováním v současné české veřejné komunikaci [Světák, dovča and comp: On Informal Expressions in Contemporary Czech Public Communication]. In H. Adam \& R. Hammel (Eds.), Sprache und Kultur der Tschechen und Slowaken und ihre Vermittlung. Beiträge zur Bohemistik und Slowakistik aus Berlin, der Tschechischen und Slowakischen Republik [Language and Culture of Czech and Slovaks and their Mediation. Contributions to Czech and Slovak Studies from Berlin, Czech and Slovak Republic] (pp. 101-111). München: Otto Sagner.

Prošek, M. (2005). O jednom typu univerbizovaných pojmenování míst na -ák [On One Type of Univerbized Place Names Ending on -ák]. Naše řeč [Our Language], 88(2), 57-66.

Schneiderová, S. (2013). Mediální diskurz [Media Discourse]. In O. Uličný \& S. Schneiderová (Eds.), Studie k moderní mluvnici češtiny 2. Komunikační situace a styl [Studies in Modern Grammar of Czech 2. Communication Situation and Style] (pp. 95-121). Olomouc: Univerzita Palackého.

Schneiderová, S. (2015). Analýza diskurzu a mediální text [Discourse Analysis and Media Text]. Praha: Academia.

Received: November 15, 2018

Accepted: December 13, 2018

Author's information:

Petr Mareš — Dr. Sci. in Philology, Professor; petr.mares@ff.cuni.cz

\section{Коллоквиальность в стиле современной чешской письменной журналистики}

\section{П. Мареш}

Карлов университет,

Чешская Республика, 11638, Прага, пл. Яна Палаха, 2

Для цитирования: Mareš, P. (2019). Colloquiality in the style of contemporary Czech journalistic writing. Медиалингвистика, 6(1), 48-59. https://doi.org/10.21638/spbu22.2019.104 (In English)

Современная чешская письменная журналистика все чаще пользуется языковыми средствами, непосредственно связанными с разговорной, спонтанной и личной коммуникацией. Этот тренд, называемый в лингвистической литературе конверзализацией, коллоквиализацией, деформализацией и т.д., в общих чертах описывается в первой части статьи. Авторы журналистских текстов употребляют коллоквиальные (или неформальные) языковые средства (так называемые коллоквиализмы) в первую очередь для того, чтобы сократить дистанцию между участниками коммуникации (автором и читателем), и для того, чтобы приблизиться к предполагаемым языковым привычкам адресатов журнальных статей. Тексты стремятся выглядеть непосредственно, легко, естественно, в них присутствует эмоциональная вовлеченность, и они привлекают внимание читателя посредством языковой конструкции. Однако по причине частого повторения коллоквиализмы в журналистских текстах нередко теряют свою привлекательность. Становится все менее заметно их отличие от синонимичных средств, которые ранее воспринимались как базовые и непризнаковые. Распространение коллоквиализмов может достигнуть стадии, когда они полностью нейтрализуются и вытеснят ранее нейтральные средства в признаковую, а иногда и периферийную области (книжность, архаичность). В основной части статьи описываются два типа коллоквиальных лексических средств в современных чешских журналистских текстах. Рассматривают- 
ся: (а) универбизованные слова (например, kulturák 'культурный центр'; lahváč ‘пивная бутылка') и сокращенные слова (например, kilák 'километр') - они короче, выразительнее и экспрессивнее, чем общепринятые выражения; (б) заимствования из немецкого, которые были классифицированы как субстандартные и экспрессивные (например, mord 'убийство').

Ключевые слова: коллоквиальность, журналистские тексты, универбизация, сокращения, заимствования из немецкого в чешском языке.

Статья поступила в редакцию 15 ноября 2018 г.; рекомендована в печать 13 декабря 2018 г.

Контактная информация:

Мареш Петр - канд. филол. наук, проф; petr.mares@ff.cuni.cz 